\title{
Fecal Incontinence: The Quality of Reported Randomized, Controlled Trials in the Last Ten Years
}

David Parés, M.D., Ph.D., • Christine Norton, Ph.D., M.A., R.N., • Sonya Chelvanayagam, M.Sc., R.N.

Abstract

PURPOSE: This study was designed to analyze the characteristics and the quality of reporting of randomized, controlled trials published during the last ten years on fecal incontinence.

METHODS: An electronic search for all randomized, controlled trials on fecal incontinence was undertaken by using the MEDLINE database via PubMed. The data collected were divided into general data, characteristics of reporting, methodology quality assessment using the Jadad scale and a validated methodology quality score (MINCIR score), evaluation of the items published in the CONSORT statement, and the journal impact factor. Reports were divided into two groups: published articles from 1996 to 2000 (Group 1), and from 2001 to 2005 (Group 2).

RESULTS: Forty-two trials fulfilled the inclusion criteria of the study (Group 1, $n=15$; and Group 2, $n$ $=27$ ). There were no significant differences in general characteristics of randomized, controlled trials between the two groups. In Group 2, there were a statistically significant higher number of studies that reported a flow chart $(P<0.001)$, written informed consent $(P=0.008)$, sample size calculation $(P=0.023)$, and withdrawals and dropouts $(P<0.001)$. We found a statistically significant higher score in Jadad scale $(P=0.046)$ and MINCIR score $(P=0.016)$ in the published studies in Group 2. Also we found higher journal impact factor of journals that published these randomized, controlled trials during the most recent years $(P=0.04)$.

CONCLUSIONS: There is a lack of high-quality reported randomized, controlled trials on fecal incontinence during the last ten years. Reports of randomized, controlled trials involving patients with fecal incontinence published after 2001 were better reported than in the previous five years.

Introduction

Fecal incontinence is a significant health care problem with more than 5 percent of communitydwelling adults reporting symptoms and approximately 1 percent experiencing symptoms that restrict their life. ${ }^{1}$ For many years evidence-based medicine has been considered the main way to advance clinical practice, replacing the traditional medical paradigm, which was based on authority and expert opinion. ${ }^{2}$ Evidence-based medicine primarily uses randomized, controlled trials to clarify the scientific basis for medical practice. A report of a randomized, controlled trial (RCT) should convey to the reader in a transparent manner why the study was undertaken and how it was conducted and analyzed. ${ }^{3}$ The assessment of the methodologic quality of a trial is closely 
intertwined with the quality of reporting, that is, the extent to which a report provides information about the design, conduct, and analysis of the trial. ${ }^{4}$

In 1996, two groups of journal editors, trialists, and methodologists independently published some recommendations on the reporting of trials. ${ }^{5}$ Later these two groups developed a common set of recommendations called a CONSORT statement (Consolidated Standards of Reporting Trials). ${ }^{3}$ The CONSORT statement comprises a checklist of essential items that should be included in reports of RCTs and a diagram for documenting the flow of participants through a trial. The objective of CONSORT was to facilitate critical appraisal and interpretation of RCTs by providing guidance to authors, peer reviewers, and editors about how to improve the reporting of their trials. ${ }^{5}$ Many major journals now insist on compliance with CONSORT when publishing RCTs

Despite all these considerations, RCTs still are not being reported adequately. ${ }^{3}$ Inadequate reporting makes the interpretation of RCT results difficult and borders on unethical practice when biased results receive false credibility. ${ }^{3}$ Although several studies have analyzed the quality of reports of RCTs in some areas of medicine, to our knowledge no study has evaluated the characteristics of RCTs published on fecal incontinence and analysed evolution in reporting over the time.$^{6-8}$ This study was designed to analyze the characteristics and the quality of reporting of randomized, controlled trials (RCTs) published during the last ten years on fecal incontinence.

\section{METHODS}

\section{Identification Criteria}

An electronic search for all randomized, controlled trials (RCTs) on fecal incontinence was undertaken by using the MEDLINE database via PubMed. The term "fecal incontinence" was searched as the main text item. Additional search strategies included: the selection "randomized controlled trial" as a type of article and publication from January 1, 1996 to December 31, 2005. Two researchers (DP and $\mathrm{CN}$ ) independently evaluated the studies that were eligible according to the identification criteria.

\section{Inclusion and Exclusion Criteria}

All studies found by the identification criteria, which focused on adult patients, were included. Nonrandomized trials, duplicated articles, or articles that presented data from a previously published RCT were excluded from the analysis. Articles in which the main outcome was not related to fecal incontinence but were identified by the search also were excluded from the study (e.g., treatment of anal fissure). Studies in which the main outcome was not fecal incontinence but some specific items related to this field were in the secondary outcomes were considered by coauthors and were included only if there was a general agreement about its relevance.

\section{Data Collection}

The available studies were read in detail, analyzed, and data were extracted. The data collected were divided into general data, characteristics of reporting, and methodology quality assessment.

\section{General Characteristics of the Articles}


In this section we included: the country of authors (or main author), the name of the journal, main fecal incontinence issue explored in the article (diagnosis, therapeutics, prevention, and follow-up), and whether a specific design was used (multicenter, double-blinded, cross-over, or placebocontrolled trial).

\section{Characteristics of Reporting}

In this section, we looked for the specific inclusion of: description of method of randomization, total number of patients randomly assigned in the study, total number of patients followed during the study, presence of a flow diagram, comments on ethical approval, on written informed consent, and finally any reference to type of support or sponsorship for the study (e.g., grant).

\section{Quality Methodology Assessment and Journal Impact Factor}

All included articles were assessed by using three systems: the Jadad scale, ${ }^{9}$ a validated methodology quality score (MINCIR score), ${ }^{10}$ and a modified evaluation of the items published in the CONSORT statement. $^{6}$

Jadad scale is a five-point scoring system that includes three items to assess the methods used to generate random assignments, methods of double-blind assessment, and a description of dropouts and withdrawals by intervention group. ${ }^{9} \mathrm{~A}$ score that represents the sum of the three items is generated, with a final score that can vary from 0 to 5 points: 0 points are for the worst methods used, and 5 points are for the best. This scale was first described for assessment of pain studies, but because it incorporates components that are directly related to the control of bias, it has been used recently in other topics. ${ }^{7,9}$

A valid and reliable scale of methodologic quality (MINCIR score) also was used. ${ }^{11}$ This scale is composed of three items: the first is related to the study design, the second to the population sample size in the study (adjusted according to the presence or absence of a sample size justification), and finally the third part is related to the methodology used in the reporting paper (objective, design, eligibility criteria, and their justification). According to this, a score which represents the sum of the three items that is generated, with a final score that can vary between 6 and 36 points, with 6 points being the worst methodologic quality study and 36 points being the best (Table 1).

Data extraction based on CONSORT reporting items were used as previously published. ${ }^{3}$ As Kober et al. ${ }^{6}$ published recently, we did not consider items that are mainly relevant for assessing external validity of a study because our goal was to analyze the reporting level of items that are important to assess potential biases. This evaluation included 12 of 22 items of the CONSORT statement as described by Kober et al. ${ }^{6}$ and an additional item, namely conflict of interest, which is considered relevant to reflect general transparency in scientific writing. ${ }^{3,6}$ Items were investigated for the available information by whether they were specifically reported in the article rather than whether they were performed during the trial.

Finally, we analyzed the journal impact factor of every journal that published each RCT included in this study. ${ }^{12}$ The journal impact factor was extracted from the last updated SCl (Science Citation Index) version available. 
Two investigators (DP and SC) completed the quality assessment independently and blinded to each other's result. Discrepancy between evaluations was solved by discussion and, if there was a lack of agreement, by the final decision of the senior author (CN).

\section{Statistical Analysis}

Data were entered into a database and were analyzed by using SPSS $\backslash$ for Windows v. 10 statistical package (SPSS, Inc., Chicago, IL). To test the effect of time of publication in the quality of reporting of RCT data, reports were divided into two groups: published articles from January 1, 1996 to December 31, 2000 (Group 1), and published articles from January 1, 2001 to December 31, 2005 (Group 2).

Continuous data were presented as a median and range in parentheses. To avoid any bias related to the asymmetrical distribution of the scores, we also used a percentile range (25th and 75th percentile). Categorical data were presented as absolute numbers or percentages.

Categorical data were compared by using the Pearson chi-squared test if at least 80 percent of the cells had an expected count of five or more and all cells had an expected count of more than one. If this assumption did not hold, Fisher's exact test was used. The continuous data were analyzed using nonparametric tests (Mann-Whitney $U$ test). Finally, the correlation between scoring systems and journal impact factor were explored by Spearman's correlation test. A bilateral P value $<0.05$ was considered statistically significant

\section{RESULTS}

Between January 1996 to December 2005, 2,844 articles were published and appeared in PubMed using the search term "fecal incontinence" (2,398 in English). Of those, there were 115 RCTs (4.1 percent), 524 reviews (18.4 percent), 287 clinical trials (10.1 percent), 121 letters ( 4.2 percent), 55 editorials ( 1.9 percent), 14 meta-analyses ( 0.5 percent), and the remaining were nonclassifiable into one of the previous groups.

Forty-two of the 115 RCTs fulfilled the inclusion criteria of the present review (Group 1, n=15; and Group 2, n=27) and 73 did not. Sixty articles were excluded because although there was some information on fecal incontinence, this was not sufficient to be evaluated in the study. The mainissue of these excluded articles were: colonic or ileal pouch $(n=16)$, chronic anal fissure $(n=11)$, hemorrhoidal disease $(n=10)$, pelvic radiotherapy $(n=8)$, fistula-in-ano $(n=4)$, community care $(n=4)$, menopause $(n=1)$, prostate disease $(n=1)$, colonoscopy $(n=1)$, colonography $(n=1)$, classification of stools $(n=1)$, constipation $(n=1)$, and diagnosis of bowel disorders $(n=1)$. Thirteen articles were excluded for other reasons: seven articles because they were not randomized or the data were extracted from a previously reported RCT; five articles because they focused on children; and one article was a study of cadavers. The appendix shows a list of the 42 RCTs that were included in the present study

Table 2 shows the general characteristics of the included articles according to the period of publication. The United Kingdom was the most common source of articles on fecal incontinence; an American journal (Diseases of the Colon \& Rectum) was the journal that published the most RCTs on fecal incontinence that fulfilled the inclusion criteria. The most common focus in the series was RCTs on treatment. Only in the last five years (Group 2) did we find multicentre trials that fulfilled the 
inclusion criteria. There were no statistically significant differences in the general characteristics between the two groups.

Table 3 shows the reported characteristics of the included articles and their quality assessment. In Group 2, there were a statistically significant higher number of articles that reported a comprehensive flow chart diagram of patients evaluated for the study $(P<0.001)$ and a specific comment about written, informed consent $(P=0.008)$. However, there were no statistical differences in the method of allocation sequence, the number of patients who were randomly assigned in all the studies, the number of patients who completed the trials, comments on ethical approval, and type of support for the study. When we evaluated the quality of reporting of RCTs we found a statistically significant higher score in Jadad score $(P=0.046)$ and MINCIR score $(P=0.016)$ in articles published during the last five years (Group 2). Also we found higher median of the journal impact factor of journals that published RCTs on fecal incontinence during the most recent years $(P=0.04)$.

Figure 1 shows the statistically significant lineal correlation between the two methods (Jadad scale and MINCIR score) of evaluating the quality of the reporting of RCTs (Rho $=0.654, \mathrm{P}<0.001$ ). Also we found a correlation between the journal impact factor and Jadad scale ( $R h o=0.315, P=0.048)$ and journal impact factor and MINCIR score (Rho=0.432, $\mathrm{P}=0.005)$.

Table 4 shows the frequency of reporting of 12 selected CONSORT items and conflict of interest item in the RCTs. The only statistically significant difference between Groups 1 and 2 was a higher proportion with any reference to sample size calculation $(P=0.023)$ and withdrawals and dropouts $(\mathrm{P}<0.001)$ in Group 2.

\section{DISCUSSION}

The clinical management of fecal incontinence is evolving.During the last ten years, more than 2,800 articles were published on this issue; however, interestingly only 4 percent of them were randomized, controlled trials (RCTs). In recent years, this type of study has become more common than it was ten years ago. For example, when we did the PubMed search we found that the number of RCTs on fecal incontinence was 6 in 1997, 14 in 2000, and 21 in 2005. However we also noted that most RCTs retrieved using the search term "faecal incontinence", did not have their main focus on faecal incontinence.

An RCT is considered the "standard" for establishing clinical effectiveness because it is well known that it minimizes bias. ${ }^{3}$ Therefore, RCT methods represent a key research activity, with the potential to improve the quality of health care and control costs through careful comparison of any alternatives. ${ }^{6}$ Given the limited number of RCTs on fecal incontinence, the methodologic limitations of the reports and the social importance of this condition it seemed timely to conduct a bibliometric analysis using comprehensive methodological quality assessment. This was our main objective for this study.

Studies in all areas of investigation, including prevention or diagnosis of fecal incontinence, are warranted. Interestingly, there were a high number of trials that focused on therapeutic issues rather than other important issues, such as diagnosis. These findings were not different from other areas. For example, in a single-year analysis of RCTs in six well-known medical journals, more than 60 percent of trials evaluated pharmacologic interventions. ${ }^{13}$ It is known that commercial interests, 
which fund many treatments, influence the interests of researchers and probably the conduct of RCTs.

Given the huge number of studies published annually in all areas of medicine, to keep up to date a clinician, according to one study, would need to read approximately 17 articles per day, every day of the year. ${ }^{14}$ Therefore, easy to-use tools that evaluate the overall quality of articles could significantly improve the efficiency of clinical readers.

Quality is a multidimensional concept, which could relate to design, conduct, analysis of a trial, its clinical relevance, or quality of reporting. ${ }^{15}$ We have enough information to support the idea that the methodologic quality of a trial is directly related to the quality of reporting. ${ }^{4}$ Reports should provide information about the design, conduct, and analysis of the trial. ${ }^{15}$ Most readers assume that the quality was inadequate unless the information to the contrary is provided. ${ }^{15}$ This often is justified because faulty reporting generally reflects faulty methods. 16 It also is interesting that lower quality studies are more likely to report positive results. ${ }^{5}$ Moreover, we should note that a well-conducted, but badly reported, trial can be misclassified, and therefore, the quality of a RCT is of obvious relevance to systematic reviews and meta-analyses. ${ }^{15}$

There have been several attempts to evaluate the quality of reports using special tools. The journal impact factor was created in the early 1960s to help select journals for the Science Citation Index $(\mathrm{SCl})$ and as a simple method for comparing journals regardless of their size. ${ }^{12}$ This score is based on two elements: 1) the numerator, which is the number of citations in the current year of any items published in a journal during the previous two years, and 2) the denominator, which is the number of substantive articles (source items) published during the same two years. ${ }^{12}$ The use of journal impact factor has evolved and has been used as a measure of quality on authors' curriculum vitae. However, the practical value and its utility have been recently questioned. ${ }^{12}$ Moreover, there are a number of other methods for quantifying the quality of trials, including the use of scores. ${ }^{9,10}$ The use of these scores permits a quick evaluation for the reader but previously the relationship between these quality scores and journal impact factor was unknown. We used two scores that have not previously been reported together to evaluate reporting quality on fecal incontinence. Interestingly, and despite the fact that the Jadad scale was described for use only for RCTs, it was statistically significantly correlated with the MINCIR score, which is not only for these types of studies. We found a statistical significant higher score from both systems in recent years. Thus, this information supports the idea that there have been more RCTs about fecal incontinence in recent years and they also have been better reported.

Some initiatives in the era of evidence-based medicine have tried to increase the quality of reporting of RCTs. The objective of CONSORT was to facilitate critical appraisal and interpretation of RCTs by providing guidance to authors, peer reviewers, and editors about how to improve the reporting of their trials.5 However, we noted that even in the most recent years (from 2001-2005) some basic descriptions in a RCT, as well as the method of randomization, are still insufficiently reported. It might be reasonable to exclude such RCTs from reviews or meta-analyses if the quality of reporting is poor.

Journal policies influence the quality of reporting. They each have different standards set for manuscript submission, different editorial processes, variation in values and emphasis among journals, and international differences in research cultures. ${ }^{8}$ However, we found, for example, that 
only Diseases of the Colon \& Rectum, Journal of the American Geriatrics Society, and The American Journal of Obstetrics and Gynaecology published more than three RCTs about fecal incontinence during the period of the study. Therefore, it was impossible to compare the different quality of reporting of each journal. However, to explore the relationship between journals and quality of report we added to the quality assessment by scores its relationship to journal impact factor. Moreover, we found a statistical correlation between Jadad and MINCIR scores and journal impact factor. There is no doubt that journals influence making explicit quality requirements for the documentation of RCTs.

\section{CONCLUSIONS}

Our results indicate that there is a lack of high-quality reported RCTs in fecal incontinence during the last ten years in all areas. We found that reports of RCTs involving patients with fecal incontinence published after 2001 were better reported. There are some quality methodologic scores that provide some assistance in the assessment of trials and they correlated to the quality of journals. Strategies to improve the quality of reporting studies are warranted

\section{REFERENCES}

1. Perry S, Shaw C, McGrother C, et al. Prevalence of faecal incontinence in adults aged 40 years or more living in the community. Gut 2002;50:480-4.

2. Evidence-based medicine. A new approach to teaching the practice of medicine. Evidence-Based Medicine Working Group. JAMA 1992;268:2420-5.

3. Moher D, Schulz KF, Altman D. The CONSORT statement: revised recommendations for improving the quality of reports of parallel-group randomized trials. JAMA 2001; 285:1987-91.

4. Huwiler-Muntener K, Juni P, Junker C, Egger M. Quality of reporting of randomized trials as a measure of methodologic quality. JAMA 2002;287:2801-4.

5. Moher D, Fortin $P$, Jadad AR, et al. Completeness of reporting of trials published in languages other than English: implications for conduct and reporting of systematic reviews. Lancet 1996;347: 363-6.

6. Kober T, Trelle S, Engert A. Reporting of randomized controlled trials in Hodgkin lymphoma in biomedical journals. J Natl Cancer Inst 2006;98:620-5.

7. Klassen TP, Pham B, Lawson ML, Moher D. For randomized controlled trials, the quality of reports of complementary and alternative medicine was as good as reports of conventional medicine. J Clin Epidemiol 2005;58:763-8.

8. Badcock D, Kelly AM, Kerr D, Reade T. The quality of medical record review studies in the international emergency medicine literature. Ann Emerg Med 2005;45:444-7.

9. Jadad AR, Moore RA, Carroll D, et al. Assessing the quality of reports of randomized clinical trials: is blinding necessary? Control Clin Trials 1996;17:1-12. 
10. Manterola C, Busquets J, Pascual M, Grande L. ¿Cuál es la calidad metodológica de los artículos sobre procedimientos terapéuticos publicados en Cirugía Española? Cir Esp 2006; 79:95-100.

11. Manterola C, Pineda V, Vial M, Losada H, MINCIR Group (Methodology and Investigations in Surgery). What is the methodological quality of human therapy studies in ISI surgical publications? Ann Surg 2006;244:827-32.

12. Garfield E. The history and meaning of the journal impact factor. JAMA 2006;295:90-3.

13. Egger M, Bartlett C, Juni P. Are randomised controlled trials in the BMJ different? BMJ 2001;323:1253-4.

14. Davidoff F, Haynes B, Sackett D, Smith R. Evidence-based medicine. BMJ 1995;310:1085-6.

15. Juni P, Altman DG, Egger M. Systematic reviews in health care: assessing the quality of controlled clinical trials. BMJ 2001;323:42-6.

16. Schulz KF, Chalmers I, Hayes RJ, Altman DG. Empirical evidence of bias. Dimensions of methodological quality associated with estimates of treatment effects in controlled trials. JAMA 1995;273:408-12.

\section{APPENDIX}

Articles Included in the Study

1. van Tets WF, Kuijpers JH, Tran K, Mollen R, van Goor H. Influence of Parks' anal retractor on anal sphincter pressures. Dis Colon Rectum 1997; 40:1042-1045.

2. Sun WM, Read NW, Verlinden M. Effects of loperamide oxide on gastrointestinal transit time and anorectal function in patients with chronic diarrhoea and faecal incontinence. Scand J Gastroenterol $1997 ; 32: 34-38$.

3. Bennett RG, Baran PJ, DeVone LV, Bacetti H, Kristo B, Tayback M, Greenough WB, III. Low airloss hydrotherapy versus standard care for incontinent hospitalized patients. J Am Geriatr Soc 1998; 46:569-576.

4. van Tets WF, Kuijpers JH. Pelvic floor procedures produce no consistent changes in anatomy or physiology. Dis Colon Rectum 1998; 41:365-369.

5. Fynes MM, Marshall K, Cassidy M, Behan M, Walsh D, O'Connell PR, O'Herlihy C. A prospective, randomized study comparing the effect of augmented biofeedback with sensory biofeedback alone on fecal incontinence after obstetric trauma. Dis Colon Rectum 1999; 42:753-758.

6. Siproudhis L, Bellissant E, Pagenault M, Mendler MH, Allain H, Bretagne JF, Gosselin M. Fecal incontinence with normal anal canal pressures: where is the pitfall? Am J Gastroenterol 1999; 94:1556-1563.

7. Nessim A, Wexner SD, Agachan F, Alabaz O, Weiss EG, Nogueras JJ, Daniel N, Billotti VL. Is bowel confinement necessary after anorectal reconstructive surgery? A prospective, randomized, surgeonblinded trial. Dis Colon Rectum 1999; 42:16-23. 
8. Yoshioka K, Ogunbiyi OA, Keighley MR. A pilot study of total pelvic floor repair or gluteus maximus transposition for postobstetric neuropathic fecal incontinence. Dis Colon Rectum 1999; 42:252-257.

9. Caplan GA, Ward JA, Brennan NJ, Coconis J, Board N, Brown A. Hospital in the home: a randomised controlled trial. Med J Aust 1999; 170:156-160.

10. Ho YH, Cheong WK, Tsang C, Ho J, Eu KW, Tang CL, Seow-Choen F. Stapled hemorrhoidectomycost and effectiveness. Randomized, controlled trial including incontinence scoring, anorectal manometry, and endoanal ultrasound assessments at up to three months. Dis Colon Rectum 2000; 43:1666-1675.

11. Fitzpatrick $M$, Behan $M, O^{\prime}$ Connell $P R$, $O^{\prime}$ Herlihy $C$. A randomized clinical trial comparing primary overlap with approximation repair of third-degree obstetric tears. Am J Obstet Gynecol 2000; 183:1220-1224.

12. Carapeti EA, Kamm MA, Nicholls RJ, Phillips RK. Randomized, controlled trial of topical phenylephrine for fecal incontinence in patients after ileoanal pouch construction. Dis Colon Rectum 2000; 43:1059-1063.

13. Hasegawa H, Yoshioka K, Keighley MR. Randomized trial of fecal diversion for sphincter repair. Dis Colon Rectum 2000; 43:961-964.

14. Chassagne P, Jego A, Gloc P, Capet C, Trivalle C, Doucet J, Denis P, Bercoff E. Does treatment of constipation improve faecal incontinence in institutionalized elderly patients? Age Ageing 2000; 29:159-164.

15. Carapeti EA, Kamm MA, Phillips RK. Randomized controlled trial of topical phenylephrine in the treatment of faecal incontinence. Br J Surg 2000; 87:38-42.

16. Cooper P, Gray D. Comparison of two skin care regimes for incontinence. Br J Nurs 2001; 10:S6, S8, S10.

17. Glazener CM, Herbison GP, Wilson PD, MacArthur C, Lang GD, Gee H, Grant AM. Conservative management of persistent postnatal urinary and faecal incontinence: randomised controlled trial. BMJ 2001; 323:593-596.

18. Bliss DZ, Jung HJ, Savik K, Lowry A, LeMoine M, Jensen L, Werner C, Schaffer K. Supplementation with dietary fiber improves fecal incontinence. Nurs Res 2001; 50:203-213.

19. Stamp G, Kruzins G, Crowther C. Perineal massage in labour and prevention of perineal trauma: randomised controlled trial. BMJ 2001; 322:1277-1280.

20. Cheetham MJ, Kamm MA, Phillips RK. Topical phenylephrine increases anal canal resting pressure in patients with faecal incontinence. Gut 2001; 48:356-359.

21. Fitzpatrick M, Harkin R, McQuillan K, O'Brien C, O'Connell PR, O'Herlihy C. A randomised clinical trial comparing the effects of delayed versus immediate pushing with epidural analgesia on mode of delivery and faecal continence. BJOG 2002; 109:1359-1365. 
22. Lewis-Byers K, Thayer D. An evaluation of two incontinence skin care protocols in a long-term care setting. Ostomy Wound Manage 2002; 48:44-51.

23. Schnelle JF, Alessi CA, Simmons SF, Al Samarrai NR, Beck JC, Ouslander JG. Translating clinical research into practice: a randomized controlled trial of exercise and incontinence care with nursing home residents. J Am Geriatr Soc 2002; 50:1476-1483.

24. Hannah ME, Hannah WJ, Hodnett ED, Chalmers B, Kung R, Willan A, Amankwah K, Cheng M, Helewa M, Hewson S, Saigal S, Whyte H, Gafni A. Outcomes at 3 months after planned cesarean vs planned vaginal delivery for breech presentation at term: the international randomized Term Breech Trial. JAMA 2002; 287:1822-1831

25. Zimmerman DD, Gosselink MP, Hop WC, Darby M, Briel JW, Schouten WR. Impact of two different types of anal retractor on fecal continence after fistula repair: a prospective, randomized, clinical trial. Dis Colon Rectum 2003; 46:1674-1679.

26. Norton C, Chelvanayagam S, Wilson-Barnett J, Redfern S, Kamm MA. Randomized controlled trial of biofeedback for fecal incontinence. Gastroenterology 2003; 125:1320-1329.

27. Solomon MJ, Pager CK, Rex J, Roberts R, Manning J. Randomized, controlled trial of biofeedback with anal manometry, transanal ultrasound, or pelvic floor retraining with digital guidance alone in the treatment of mild to moderate fecal incontinence. Dis Colon Rectum 2003; 46:703-710.

28. Fitzpatrick M, Behan M, O'Connell PR, O'Herlihy C. Randomised clinical trial to assess anal sphincter function following forceps or vacuum assisted vaginal delivery. BJOG 2003; 110:424-429.

29. Bates-Jensen BM, Alessi CA, Al Samarrai NR, Schnelle JF. The effects of an exercise and incontinence intervention on skin health outcomes in nursing home residents. J Am Geriatr Soc 2003; 51:348-355.

30. Schnelle JF, Kapur K, Alessi C, Osterweil D, Beck JG, Al Samarrai NR, Ouslander JG. Does an exercise and incontinence intervention save healthcare costs in a nursing home population? J Am Geriatr Soc 2003; 51:161-168.

31. Tjandra JJ, Lim JF, Hiscock R, Rajendra P. Injectable silicone biomaterial for fecal incontinence caused by internal anal sphincter dysfunction is effective. Dis Colon Rectum 2004; 47:2138-2146.

32. O'Brien PE, Dixon JB, Skinner S, Laurie C, Khera A, Fonda D. A prospective, randomized, controlled clinical trial of placement of the artificial bowel sphincter (Acticon Neosphincter) for the control of fecal incontinence. Dis Colon Rectum 2004; 47:1852-1860.

33. Harari D, Norton C, Lockwood L, Swift C. Treatment of constipation and fecal incontinence in stroke patients: randomized controlled trial. Stroke 2004; 35:2549-2555.

34. Mahony RT, Malone PA, Nalty J, Behan M, O'Connell PR, O'Herlihy C. Randomized clinical trial of intra-anal electromyographic biofeedback physiotherapy with intra-anal electromyographic biofeedback augmented with electrical stimulation of the anal sphincter in the early treatment of postpartum fecal incontinence. Am J Obstet Gynecol 2004; 191:885-890. 
35. Osterberg A, Edebol Eeg-Olofsson K, Hallden M, Graf W. Randomized clinical trial comparing conservative and surgical treatment of neurogenic faecal incontinence. Br J Surg 2004; 91:11311137.

36. Davis KJ, Kumar D, Poloniecki J. Adjuvant biofeedback following anal sphincter repair: a randomized study. Aliment Pharmacol Ther 2004; 20:539-549.

37. Fox M, Thumshirn M, Menne D, Stutz B, Fried M, Schwizer W. The pathophysiology of faecal spotting in obese subjects during treatment with orlistat. Aliment Pharmacol Ther 2004; 19:311321.

38. Leroi AM, Parc Y, Lehur PA, Mion F, Barth X, Rullier E, Bresler L, Portier G, Michot F. Efficacy of sacral nerve stimulation for fecal incontinence: results of a multicentre double-blind crossover study. Ann Surg 2005; 242:662-669.

39. Fox M, Stutz B, Menne D, Fried M, Schwizer W, Thumshirn M. The effects of loperamide on continence problems and anorectal function in obese subjects taking orlistat. Dig Dis Sci 2005; 50:1576-1583.

40. Faltin DL, Boulvain M, Floris LA, Irion O. Diagnosis of anal sphincter tears to prevent fecal incontinence: a randomized controlled trial. Obstet Gynecol 2005; 106:6-13.

41. Garcia V, Rogers RG, Kim SS, Hall RJ, Kammerer-Doak DN. Primary repair of obstetric anal sphincter laceration: a randomized trial of two surgical techniques. Am J Obstet Gynecol 2005; 192:1697-1701.

42. Inyckyj A, Fachnie E, Tougas G. A randomized-controlled trial comparing an educational intervention alone vs education and biofeedback in the management of faecal incontinence in women. Neurogastroenterol Motil 2005; 17:58-63.

Table 1: Methodologic quality score (MINCIR score) ${ }^{10}$

\begin{tabular}{|c|c|}
\hline Item & Score \\
\hline 1. Study design & \\
\hline Multicenter, clinical trial & 12 \\
\hline Randomized, clinical trial (double-blind)* & 9 \\
\hline $\begin{array}{l}\text { Clinical trial (simple blind or nonblinded, } \\
\text { nonrandomized) }{ }^{\dagger}\end{array}$ & 6 \\
\hline Concurrent cohort studies & 4 \\
\hline Case-control studies and historic cohort studies & 3 \\
\hline Cross-sectional studies & 3 \\
\hline Case series & 1 \\
\hline 2. Studied population $\times$ justification factor ${ }^{\ddagger}$ & \\
\hline$\geq 201$ & 6 or 12 \\
\hline $151-200$ & 5 or 10 \\
\hline $101-150$ & 4 or 8 \\
\hline 61-100 & 3 or 6 \\
\hline $31-60$ & 2 or 4 \\
\hline
\end{tabular}




\begin{tabular}{|l|l|}
\hline$\leq 30$ & 1 or 2 \\
\hline 3. Methodology & \\
Objective & 3 \\
Precise and definite objectives are presented & 2 \\
Imprecise objectives are presented & 1 \\
No objectives are presented & \\
Design & 3 \\
The design used is mentioned and justified & 2 \\
The design used is only mentioned & 1 \\
The design used is neither mentioned nor justified & \\
Selection criteria & 3 \\
Inclusion and exclusion criteria are described & 2 \\
Inclusion or exclusion criteria are described & 1 \\
No selection criteria are described & 3 \\
Sample size & 1 \\
Justified sample size & Score 6 to 36 \\
Nonjustified sample size & Final score=ITEM 1+ITEM 2+ITEM 3
\end{tabular}

*Includes clinical trials with restricted randomization and quasi-experimental studies.

†Includes experimental studies (prepost). _ $¥$ Justification factor is $x 2$ if the sample was justified and $x 1$ if it was a nonjustified sample size

Table 2. General characteristics data of $\mathbf{4 2}$ randomized, controlled trials for fecal incontinence according to period of publication

\begin{tabular}{|c|c|c|c|}
\hline & $\begin{array}{l}\text { Group 1 } \\
1996-2000 \\
(n=15)\end{array}$ & $\begin{array}{l}\text { Group 2 } \\
2001-2005 \\
(n=27)\end{array}$ & P value* \\
\hline $\begin{array}{l}\text { Country } \\
\text { United Kingdom } \\
\text { United States of America } \\
\text { Australia } \\
\text { Ireland } \\
\text { Others }\end{array}$ & $\begin{array}{l}5(33.3) \\
2(13.3) \\
1(6.6) \\
2(13.3) \\
5(33.3)\end{array}$ & $\begin{array}{l}6(22.2) \\
5(18.5) \\
4(14.8) \\
3(11.1) \\
9(33.3)\end{array}$ & 0.518 \\
\hline $\begin{array}{l}\text { Journal } \\
\text { Dis Colon Rectum } \\
\text { J Am Geriatr Soc } \\
\text { Am J Obstet Gynecol } \\
\text { Others }\end{array}$ & $\begin{array}{l}8(53.3) \\
1(6.6) \\
1(6.6) \\
5(33.3)\end{array}$ & $\begin{array}{l}4(14.8) \\
3(11.1) \\
2(7.4) \\
18(66.7)\end{array}$ & 0.383 \\
\hline $\begin{array}{l}\text { Main issue } \\
\text { Diagnosis } \\
\text { Therapeutics } \\
\text { Prevention } \\
\text { Follow-up }\end{array}$ & $\begin{array}{l}1(6.6) \\
10(66.7) \\
4(26.7) \\
-\end{array}$ & $\begin{array}{l}- \\
17(62.9) \\
9(33.3) \\
1(3.7)\end{array}$ & 0.44 \\
\hline $\begin{array}{l}\text { Type of RCT } \\
\text { Multicenter trial } \\
\text { Double-blinded trial } \\
\text { Cross-over trial } \\
\text { Placebo-controlled trial }\end{array}$ & $\begin{array}{l}- \\
3(20) \\
3(20) \\
3(20)\end{array}$ & $\begin{array}{l}5(18.5) \\
4(14.8) \\
2(7.4) \\
1(3.7)\end{array}$ & $\begin{array}{l}0.101 \\
0.608 \\
0.251 \\
0.077\end{array}$ \\
\hline
\end{tabular}

${ }^{*}$ Chi-squared test. _ Data are numbers with percentages in parentheses unless otherwise indicated. 
Table 3. Reporting characteristics and quality assessment of randomized, controlled trials according to period of publication

\begin{tabular}{|c|c|c|c|}
\hline & $\begin{array}{l}\text { Group } 1 \\
1996-2000 \\
(n=15)\end{array}$ & $\begin{array}{l}\text { Group } 2 \\
2001-2005 \\
(n=27)\end{array}$ & P value* \\
\hline $\begin{array}{l}\text { Method of random allocation } \\
\text { sequence } \\
\text { Computer random } \\
\text { Sealed envelopes only } \\
\text { Table with random numbers } \\
\text { Other } \\
\text { No mention }\end{array}$ & $\begin{array}{l}5(33.3) \\
2(13.3) \\
1(6.6) \\
1(6.6) \\
6(40) \\
\end{array}$ & $\begin{array}{l}16(59.2) \\
3(11.1) \\
1(3.7) \\
1(3.7) \\
6(22.2)\end{array}$ & $0.599 *$ \\
\hline $\begin{array}{l}\text { No. of patients randomly } \\
\text { assigned } \\
\text { No. of patients completed the } \\
\text { study }\end{array}$ & $\begin{array}{l}40(11-206) \\
39(11-178)\end{array}$ & $\begin{array}{l}82(10-2,088) \\
82(8-1,596)\end{array}$ & $\begin{array}{l}0.128^{\dagger} \\
0.253^{+}\end{array}$ \\
\hline Flow chart diagram & - & $14(51.8)$ & $<0.001 *$ \\
\hline $\begin{array}{l}\text { Comments on ethical } \\
\text { approval }\end{array}$ & $13(86.7)$ & $24(88.9)$ & $1^{*}$ \\
\hline Written, informed consent & $7(46.7)$ & $24(88.9)$ & $0.008^{*}$ \\
\hline $\begin{array}{l}\text { Support } \\
\text { Grant } \\
\text { Company } \\
\text { No mention } \\
\end{array}$ & $\begin{array}{l}6(40) \\
3(20) \\
6(40) \\
\end{array}$ & $\begin{array}{l}16(59.2) \\
4(14.8) \\
7(26) \\
\end{array}$ & $0.483^{*}$ \\
\hline $\begin{array}{l}\text { Jadad scale (maximum 5) } \\
\text { Median (range) } \\
\text { Percentile25th- }-75^{\text {th }}\end{array}$ & $\begin{array}{l}2(0-4) \\
0-3\end{array}$ & $\begin{array}{l}3(0-5) \\
2-3\end{array}$ & $0.046^{*}$ \\
\hline $\begin{array}{l}\text { MINCIR score (maximum 36) } \\
\text { Median (range) } \\
\text { Percentile25th-75th }\end{array}$ & $\begin{array}{l}19(13-25) \\
15-20\end{array}$ & $\begin{array}{l}23(13-36) \\
17-27\end{array}$ & $0.016^{*}$ \\
\hline $\begin{array}{l}\text { Impact factor } \\
\text { Median (range) } \\
\text { Percentile25th-75th }\end{array}$ & $\begin{array}{l}2.26(1.79-4.71) \\
2.26-3.08\end{array}$ & $\begin{array}{l}3.43(1.38-23.5) \\
2.26-6.09\end{array}$ & $0.04^{*}$ \\
\hline
\end{tabular}

Data are numbers with percentages in parentheses or medianswith ranges in parentheses unless otherwise indicated. _ ${ }^{*}$ Nonparametric test (Mann-Whitney $U$ test). _ ${ }^{+C h i-s q u a r e d ~ t e s t . ~}$

Table 4. Frequency of reporting of 13 data items (modified CONSORT checklist) of the $\mathbf{4 2}$ randomized, controlled trials for fecal incontinence by period of publication

\begin{tabular}{|c|c|c|c|c|}
\hline Item* & Section and topic & $\begin{array}{l}\text { Group } 1 \text { 1996-2000 } \\
(n=15)\end{array}$ & $\begin{array}{l}\text { Group } 2 \text { 2001- } \\
2005(n=27)\end{array}$ & $\mathrm{P}$ value ${ }^{\dagger}$ \\
\hline 1 & $\begin{array}{l}\text { Randomized in Title } \\
\text { Abstract only } \\
\text { No mention }\end{array}$ & $\begin{array}{l}8(53.3) \\
7(47.7) \\
- \\
\end{array}$ & $\begin{array}{l}17(62.8) \\
9(33.3) \\
1(3.7) \\
\end{array}$ & 0.561 \\
\hline 2 & $\begin{array}{l}\text { Scientific background and } \\
\text { purpose described }\end{array}$ & $14 / 15(93.3)$ & $27 / 27(100)$ & 0.357 \\
\hline 4 & Details of intervention in each & $15 / 15(100)$ & $27 / 27(100)$ & NC \\
\hline
\end{tabular}




\begin{tabular}{|l|l|l|l|l|}
\hline & arm & & & \\
\hline 7 & Calculation of sample size & $3 / 15(20)$ & $16 / 27(59.2)$ & 0.023 \\
\hline 8 & $\begin{array}{l}\text { Method of randomization } \\
\text { described }\end{array}$ & $9 / 15(60)$ & $20 / 27(74.1)$ & 0.488 \\
\hline 9 & $\begin{array}{l}\text { Adequate concealment of } \\
\text { allocation }\end{array}$ & $5 / 15(33.3)$ & $18 / 27(66.7)$ & 0.055 \\
\hline 12 & Statistical methods described & $15 / 15(100)$ & $26 / 27(96.2)$ & 1 \\
\hline 13 & $\begin{array}{l}\text { Withdrawals and dropouts } \\
\text { reported }\end{array}$ & $2 / 15(13.3)$ & $22 / 27(81.5)$ & $<0.001$ \\
\hline 16 & Intention to treat & $3 / 10(30)$ & $3 / 14(21.4)$ & 0.764 \\
\hline 17 & Primary outcomes & $13 / 15(86.7)$ & $26 / 27(96.2)$ & 0.287 \\
\hline 19 & Adverse events reported & $10 / 11(90.1)$ & $12 / 17(81.5)$ & 0.466 \\
\hline 20 & Summary of results & $15 / 15(100)$ & $27 / 27(100)$ & $\mathrm{NC}$ \\
\hline $\mathrm{NI}$ & Conflict of interest declaration & $2 / 15(13.3)$ & $5 / 27(18.5)$ & 1 \\
\hline
\end{tabular}

$\mathrm{NC}=$ not compared; $\mathrm{NI}=$ not included in CONSORT. _ Data are numbers with percentages in parentheses unless otherwise indicated. _ ${ }^{*}$ Item number according to CONSORT checklist. ${ }^{3}{ }_{-}{ }^{+}$Chisquared test.

Figure 1: Results of the Spearman's correlation test between JADAD scale score and MINCIR score in the evaluation of reporting quality methodology of the randomized, controlled trials included.

MINCIR score (from 6 to 36 )

40

Group 2 (2001-2005)

Group 1 (1996-2000)

Rho $=0.654, \mathrm{p}<0.001$

30

20

$\begin{array}{llllrrrrr}-1 & 0 & 1 & 2 & 3 & 4 & 5 & 6\end{array}$

